\title{
Enzymatic hydrolysis of camel milk casein and its antioxidant properties
}

\author{
Devendra Kumar ${ }^{1}$ - Manish Kumar Chatli $^{1}$ • \\ Raghvendar Singh $^{2} \cdot$ Nitin Mehta $^{1} \cdot$ Pavan Kumar $^{1}$
}

Received: 13 August 2015 /Revised: 30 November 2015 / Accepted: 3 December 2015 /

Published online: 5 January 2016

C) INRA and Springer-Verlag France 2016

\begin{abstract}
The aim of this work was to investigate the enzymatic hydrolysis of whole casein from camel milk with proteolytic enzymes, viz. alcalase, $\alpha$-chymotrypsin and papain, and to assess the antioxidant activity of hydrolysates. Casein powder was reconstituted (5\% TS) and the selected enzymes were added at 1:100 (enzyme/substrate). Hydrolysis was carried out for $6 \mathrm{~h}$ at $55^{\circ} \mathrm{C}$ for alcalase and papain and $37^{\circ} \mathrm{C}$ for $\alpha$-chymotrypsin, and samples were drawn at 2-h interval. The hydrolysates were analysed for $\mathrm{pH}$, degree of hydrolysis $(\mathrm{DH})$ and antioxidant activities, viz. 2, 2'azinobis (3-ethylbenzthiazoline-6-sulphonic acid) (ABTS), 2, 2'-diphenyl-1picrylhydrazyl (DPPH) and ferric reducing antioxidant power (FRAP) assay. The decrease in $\mathrm{pH}$ of the hydrolysates was observed with the progress of hydrolysis time, and as compared to alcalase, the rate of $\mathrm{pH}$ decrease was higher for $\alpha$-chymotrypsin and papain. The DH increased significantly $(P<0.05)$ up to $6 \mathrm{~h}$ on hydrolysis with alcalase and papain, whereas with chymotrypsinolysis, DH increased significantly $(P<0.05)$ up to $4 \mathrm{~h}$; thereafter, a non-significant increase was observed. The antioxidant activity assessed by ABTS, DPPH and FRAP assay increased significantly $(P<0.05)$ with the increase in hydrolysis time as well as the degree of hydrolysis. The chymotrypsinolysis exhibited higher antioxidant activity as compared to alcalase and papain. The results obtained in this study suggested that camel milk casein could be used as an ingredient in nutraceuticals or health-oriented foods.
\end{abstract}

Keywords Camel milk Enzymatic hydrolysis $\cdot$ Casein hydrolysate $\cdot$ Degree of hydrolysis $\cdot$ Antioxidant activity

Devendra Kumar

drdev24@gmail.com

1 Department of Livestock Products Technology, College of Veterinary Science, Guru Angad Dev Veterinary and Animal Sciences University, Ludhiana 141004 Punjab, India

2 National Research Centre on Camel, P.B. No. 07, Bikaner, Rajasthan, India 


\section{Introduction}

The one-humped camels (Camelus dromedarius) are well-known producers of milk which differs from bovine milk in the composition and structure of its protein content and thus has different functional and medicinal properties. Caseins $(\mathrm{CNs})$ are the major proteins in camel milk, and $\alpha-, \beta$ - and $\mathrm{k}-\mathrm{CN}$ constitutes about 65,21 and $3.47 \%$ respectively, of total caseins (Kappeler et al. 2003). Camel milk shows similarity to human milk as it contains a high amount of $\beta-\mathrm{CN}$; this could reflect its higher digestibility and lower incidence of allergy in infants, as $\beta-\mathrm{CN}$ is more sensitive to peptic hydrolysis than $\alpha-\mathrm{CN}$ (El-Agamy et al. 2009). The estimated molecular masses of $\beta-\mathrm{CN}$ and $\alpha-\mathrm{CN}$ in camel milk using SDS-PAGE technique were reported to be $28.6 \mathrm{kDa}$ (Mohamed 1993) and $35 \mathrm{kDa}$ (Farah 1996), respectively, which is higher than those in bovine milk casein. Camel milk $\alpha$-lactalbumin was reported to have a molecular weight of $14.6 \mathrm{kDa}$ having 123 residues, which is similar to that of bovine, human and goat milk (Beg et al. 1985).

The peptides derived from milk proteins have been shown to exert various functionalities such as antioxidant activities, anti-cancer activities, reduction of blood pressure (ACE), opioid activities, mineral binding, growth stimulation and antimicrobial activities (Clare and Swaisgood 2000; Meisel 2005). Hence, caseins may play important biological functions after being hydrolyzed with different proteases. Some of the authors also reported that casein-derived bioactive peptides decrease the risk of heart disease, diabetes and cancer (Rival et al. 2001; Aimutis 2004). The antioxidant properties of the peptides are related to their composition, structure and hydrophobicity (Chen et al. 1998), position of amino acid residue (Chen et al. 1995) and molecular weight (Li et al. 2008).

The bioactivity of peptides obtained from camel milk casein has not been extensively studied so far. Salami et al. (2008) reported higher extent of hydrolysis of camel caseins than that of bovine caseins upon treatment with pancreatic enzymes. Antimicrobial, radical-scavenging and angiotensin 1converting enzyme inhibitory activities of camel milk have also been studied by Jrad et al. (2014), after hydrolysis by pepsin and pancreatin. Despite that, recent studies suggested that camel milk could have significant therapeutic attributes such as anti-cancer and anti-diabetic properties (Agrawal et al. 2003; Magjeed 2005), search for milk-based bioactive peptides has been focused until now mainly on bovine and to smaller extent on ovine and caprine milk proteins.

Therefore, this study was undertaken to produce casein hydrolysates from camel milk using proteolytic enzymes from different sources such as alcalase (microbial), $\alpha$-chymotrypsin (animal) and papain (plant) and to investigate the antioxidant activity of the hydrolysates. All the three enzymes are endopeptidase and have been proven as one of the best enzymes for preparation of food protein hydrolysates (Rossini et al. 2009; Centenaro et al. 2014; Salami et al. 2011). The enzyme $\alpha$-chymotrypsin was selected to explore the possible effect through gastrointestinal digestion whereas the other two enzymes, alcalase and papain, were used to compare the activity in same hydrolysis conditions and possibility to explore the large-scale production. 


\section{Materials and methods}

\subsection{Chemical and reagents}

Enzyme alcalase (EC 3.4.21.62, activity $\geq 5$ units.g $^{-1}$ protein) was procured from Sigma-Aldrich Chemical Co., India, and $\alpha$-chymotrypsin (EC 3.4.21.1, activity 35 units. $\mathrm{mg}^{-1}$ protein) and papain (EC.3.4.22.2, activity $\geq 10$ units. $\mathrm{mg}^{-1}$ protein) were procured from MP Biomedicals, India. Fine chemicals such as 2, 2'-azinobis (3ethylbenzthiazoline-6-sulphonic acid) (ABTS), 2, 2'-diphenyl-1-picrylhydrazyl (DPPH) were obtained from Sigma-Aldrich Chemical Co., India, and 2, 4, 6tripyridyl-s-triazine (TPTZ) was purchased from MP Biomedicals, India. Other chemicals were of analytical grade from reputed companies and used without further purification. All solutions, prepared with double-distilled water, were kept at $4{ }^{\circ} \mathrm{C}$ before further use.

\subsection{Camel milk casein powder preparation}

Fresh camel milk was collected from dromedary camels (C. dromedarius) maintained at the Camel Dairy Farm, National Research Centre on Camel, Bikaner, and immediately cooled to below $5{ }^{\circ} \mathrm{C}$ for further use. The camel milk casein powder (CMCP) was prepared in Camel Milk Product Laboratory, NRC on Camel, Bikaner, Rajasthan. The CMCP was prepared according to the process described by Salami et al. (2011) with slight modification. The fresh camel milk was pre-heated to $37^{\circ} \mathrm{C}$ and skimmed using a cream separator. The $\mathrm{pH}$ of skim milk was adjusted to 4.6 with $1 \mathrm{~N} \mathrm{HCl}$. Then, the solution was mixed at $37{ }^{\circ} \mathrm{C}$ for $30 \mathrm{~min}$ and caseins $(\mathrm{CNs})$ were precipitated and separated from whey proteins by centrifugation $\left(10,000 \mathrm{rpm}, 60 \mathrm{~min}, 4{ }^{\circ} \mathrm{C}\right)$, and then washed three times with distilled water, lyophilized (Christ Alpha 2-4 LD Freeze Dryer, SciQuip Ltd., UK) and stored at $-20{ }^{\circ} \mathrm{C}$ until use.

\subsection{Enzymatic hydrolysis of CMCP}

Camel milk casein powder was reconstituted (5\% total solid) in phosphate buffer of different $\mathrm{pHs}$ (8.0 for alcalase and $\alpha$-chymotrypsin and 6.5 for papain) for optimum enzymatic action. The reconstituted casein solution was then heated in boiling water bath (Equitron, Model: 8414, Medica Instrument Mfg. Co., Mumbai, India) for 5 min to kill the microorganisms, if present, which may produce proteolytic enzymes during the hydrolysis process, to denature the indigenous enzymes of milk, if present, as well as to heat denature the proteins, which increases its susceptibility to proteolytic enzymes. The optimum $\mathrm{pH}$ and temperature for the hydrolysis experiment were standardized by preliminary trials and by consulting the manufacturer's instructions as well as available literature. The enzyme/substrate ratio ( $E: S$ ratio) was kept constant (1:100) for all the proteases. The hydrolysis was carried out by incubating the samples at $55{ }^{\circ} \mathrm{C}$ for alcalase and papain and $37{ }^{\circ} \mathrm{C}$ for $\alpha$-chymotrypsin in stirred water bath, and samples were drawn at the 0th, 2nd, 4th, and 6th hour of incubation. Each hydrolyzed sample was immediately heated to $85{ }^{\circ} \mathrm{C}$ for $15 \mathrm{~min}$ in water bath to inactivate the enzymes left in the hydrolysates. Then, the samples were cooled and centrifuged in a refrigerated centrifuge (Eltek, Model:MP 400R, Elektrocraft (India) 
Pvt. Ltd., Mumbai, India) at 10,000 rpm for $25 \mathrm{~min}$; supernatants were collected and stored at $-20{ }^{\circ} \mathrm{C}$ until further use.

\section{$2.4 \mathrm{pH}$ measurement}

The $\mathrm{pH}$ of hydrolysate samples was measured using combined glass electrode of Mettler Toledo pH meter (Model FiveEasy ${ }^{\text {TM }}$ plus FEP 20, Switzerland). The pH of each sample was measured just before heating to inactivate the residual enzyme.

\subsection{Determination of degree of hydrolysis}

The degree of hydrolysis $(\mathrm{DH})$ of casein hydrolysates was determined by the percentage of solubilized protein in $10 \%(w / v)$ trichloroacetic acid (TCA), in relation to the total protein content of the sample according to Hoyle and Merritt (1994), with modifications. Aliquots of $500 \mu \mathrm{L}$ of the hydrolyzed protein were mixed with $500 \mu \mathrm{L}$ of $20 \%(w / v)$ of TCA solution to obtain the soluble and insoluble fractions in $10 \%$ TCA. After 30 min of rest, the mixture was centrifuged (Cooling Microfuge Model CM 12, Remi Elektrotechnik Ltd, Vasai, India) at $3500 \mathrm{rpm}$ for $15 \mathrm{~min}$, and the soluble protein content of the supernatant was determined by the method of Lowry et al. (1951), modified by Hartree (1972). Bovine serum albumin (BSA) was used as the standard. The DH was calculated according to the following equation:

$$
\mathrm{DH}(\%)=[\text { Solubilized protein content in } 10 \% \mathrm{TCA}(\mathrm{mg}) / \text { Total protein content }(\mathrm{mg})] \times 100 .
$$

\subsection{SDS-polyacrylamide gel electrophoresis}

SDS-PAGE was performed on a $4.0 \%(w / v)$ polyacrylamide in $0.125 \mathrm{M}$ Tris- $\mathrm{HCl}$ buffer, $\mathrm{pH} 6.8$ stacking gel, and a $16.5 \%(w / v)$ polyacrylamide in $0.38 \mathrm{M}$ Tris- $\mathrm{HCl}$ buffer, $\mathrm{pH} 8.8$ containing $0.1 \%(w / v)$ SDS separation gel. Samples were mixed in equal proportion in sample buffer containing $2 \mathrm{mg} \cdot \mathrm{mL}^{-1}$ in $0.125 \mathrm{M}$ Tris- $\mathrm{HCl}$ buffer $(\mathrm{pH}$ 6.8), $0.1 \%(w / v)$ SDS, $5 \%(v / v)$ 2-mercaptoethanol, $10 \%(v / v)$ glycerol and $0.01 \%(w / v)$ bromophenol blue. After heating the mixture at $100{ }^{\circ} \mathrm{C}$ for $5 \mathrm{~min}, 20 \mu \mathrm{L}$ of sample was loaded in the gel. The molecular mass standard used was of low range, 650066,000 Da (M3913-1VL, Sigma ${ }^{\mathrm{TM}}$ chemical CO, Missouri, USA). After running the electrophoresis unit at 25-mA constant current for about 9-10 h, the gel slabs were taken out carefully and proteins were fixed with $12 \%(w / v)$ trichloroacetic acid (TCA) for $30 \mathrm{~min}$ and then stained overnight with $0.1 \%(w / v)$ R-250 Coomassie brilliant blue dissolved in a mixture of methanol/acetic acid/water $(50: 10: 40, v / v / v)$, followed by destaining in a solution containing methanol, acetic acid and water in the ratio of 45:10:45.

\section{7 $\mathrm{ABTS}^{+}$radical-scavenging activity}

The spectrophotometric analysis of $\mathrm{ABTS}^{+}$radical-scavenging activity was determined according to method described by described by Salami et al. (2009). ABTS radical cation $\left(\mathrm{ABTS}^{+}\right.$) was produced by reacting $\mathrm{ABTS}^{+}$stock solution with equal volume of 
$2.45 \mathrm{mM}$ potassium persulphate $\left(\mathrm{K}_{2} \mathrm{~S}_{2} \mathrm{O}_{8}\right)$ and allowing the mixture to stand in the dark at room temperature for $16 \mathrm{~h}$ before use. Prior to use, the stock solution was diluted with ethanol to an absorbance of 0.70 at $t_{0}(t=0 \mathrm{~min})$ and equilibrated at $30{ }^{\circ} \mathrm{C}$ exactly $6 \mathrm{~min}$ after initial mixing. About $1 \mathrm{~mL}$ of $\mathrm{ABTS}^{+}$working standard solution was mixed with $10 \mu \mathrm{L}$ of hydrolysate/standard and absorbance was measured after $20 \min \left(t_{20}\right)$ at $734 \mathrm{~nm}$ in multimode reader (Synergy H1 Hybrid Multi-Mode Microplate Reader, BioTek India, Mumbai). The $\mathrm{ABTS}^{+}$activity was calculated by using the following formula:

$\operatorname{ABTS}$ activity $(\%$ inhibition $)=\left[\left(0.7-\mathrm{At}_{20}\right) / 0.7\right] \times 100$.

\subsection{DPPH radical-scavenging activity}

The ability to scavenge 2, 2'-diphenyl-1-picrylhydrazyl (DPPH) radical by added antioxidants in samples was estimated following the method of Brand-Williams et al. (1995) with slight modification. One milliliter of DPPH reagent $(100 \mu \mathrm{M})$ was mixed with $0.25 \mathrm{~mL}$ of $0.1 \mathrm{M}$ Tris- $\mathrm{HCl}$ buffer $(\mathrm{pH} 7.4)$ and $25 \mu \mathrm{L}$ of hydrolysate sample in test tubes. The content was gently mixed and the absorbency in time $t=0 \min \left(t_{0}\right)$ was measured at $517 \mathrm{~nm}$ using a multimode reader (Synergy H1 Hybrid Multi-Mode Microplate Reader, BioTek India, Mumbai). The sample tubes were also incubated at room temperature under dark for measurement of absorbency in time $t=20 \min \left(t_{20}\right)$. Ethanol was used as blank. The free radical-scavenging activity was calculated as decrease in absorbance from the following equation:

$$
\text { Scavenging activity }(\% \text { inhibition })=100-\left[\left(\mathrm{At}_{20} / \mathrm{At}_{0}\right) \times 100\right]
$$

\subsection{Ferric reducing antioxidant power assay}

The ferric reducing antioxidant power (FRAP) was assessed according to Benzie and Strain (1999) using a multimode reader. Briefly, $900 \mu \mathrm{L}$ of working FRAP reagent (300 mM acetate buffer, $\mathrm{pH}$ 3.6: $20 \mathrm{mM}$ ferric chloride solution: $10 \mathrm{mM}$ TPTZ in $40 \mathrm{mM} \mathrm{HCl}:: 10: 1: 1)$ prepared fresh was mixed with $100 \mu \mathrm{L}$ of hydrolysate sample; the absorbance at $593 \mathrm{~nm}$ was recorded using multimode reader (Synergy H1 Hybrid MultiMode Microplate Reader, BioTek India, Mumbai) after a 40-min incubation at $37^{\circ} \mathrm{C}$. FRAP values were obtained by comparing the absorption change in the test mixture with those obtained from increasing concentrations of $\mathrm{Fe}^{3+}$ and expressed as millimoles of $\mathrm{Fe}^{2+}$ equivalents per milliliter of sample. Ferrous sulphate was used as standard for standard curve preparation.

\subsection{Statistical analysis}

Hydrolysis experiments were repeated three times and all the parameters were analysed in triplicate $(n=9)$. Data were expressed as means with standard error. Two-way analysis of variance (ANOVA) was done by comparing the means by using Duncan's multiple range test (DMRT), at 95\% confidence level using a SPSS package (SPSS 17.0 for Windows, SPSS Inc., USA).

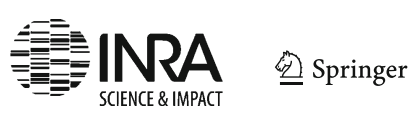




\section{Results}

\subsection{Change in pH during hydrolysis}

Although a specific initial $\mathrm{pH}$ was maintained for each enzyme to start the reaction, but due to non-monitoring in further course of reaction, a significant $(P<0.05)$ decrease in $\mathrm{pH}$ values of the hydrolysates was observed with the advancement of hydrolysis time (Fig. 1). The initial $\mathrm{pH}$ values, viz. 7.98, 7.97 and 6.49, for alcalase, $\alpha$-chymotrypsin and papain, dropped significantly to 7.76, 7.69 and 6.30 , respectively, after $6 \mathrm{~h}$ of hydrolysis. As compared to alcalase-treated samples, the rate of $\mathrm{pH}$ decrease was higher for $\alpha$-chymotrypsin, followed by papain-treated samples.

\subsection{Degree of hydrolysis}

The DH of food proteins is the measure of the soluble peptide released during hydrolysis, and it affects the antioxidant activity of protein hydrolysates. The progression in $\mathrm{DH}$ during the hydrolysis of camel milk casein by proteases is shown in Fig. 2. The DH increased significantly $(P<0.05)$ with the increase in duration of hydrolysis. Perusal of Fig. 2 revealed that initially, the rate of DH increased linearly up to $2 \mathrm{~h}$; thereafter, the rate of DH decreased and, subsequently, it got stabilized. The reduction in hydrolysis rate over time may indicate the decreased availability of cleavable peptide bonds within the substrate. The hydrolysis curve for all the three enzymes showed a high initial rate of reaction in the first $2 \mathrm{~h}$, but the proteolytic rate slowed down gradually in the following time. In the alcalase- and papain-treated caseins, the DH increased significantly $(P<0.05)$ from 0 to $6 \mathrm{~h}$ but in case of $\alpha$-chymotrypsin, the DH increased significantly $(P<0.05)$ up to $4 \mathrm{~h}$; thereafter, the increase was non-significant. The alcalase-treated casein showed higher DH for first $2 \mathrm{~h}$ as compared to other two enzymes; however, at 4 and $6 \mathrm{~h}$, the $\mathrm{DH}$ values for $\alpha$-chymotrypsin-treated casein had significantly $(P<0.05)$ higher DH followed by those of alcalase- and papain-treated caseins.

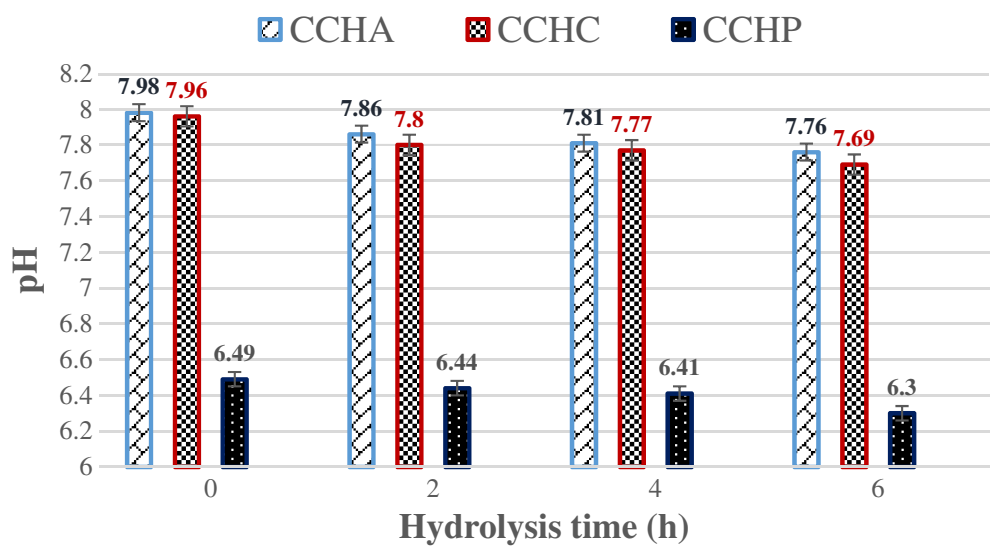

Fig. 1 Change in $\mathrm{pH}($ mean $\pm \mathrm{SE})$ of camel milk casein hydrolysates with different enzymes in the course of hydrolysis ( $C C H A$ camel casein hydrolysate with alcalase, $C C H C$ camel casein hydrolysate with chymotrypsin, CCHP camel casein hydrolysate with papain) $(n=9)$ 


\subsection{SDS-polyacrylamide gel electrophoresis}

The samples of reconstituted camel milk casein, its different hydrolysate samples, were compared with the standard molecular weight marker (Fig. 3). In the hydrolysate samples (lanes 3-10), the disappearance of bands of major proteins as of whole casein (lane 2) and appearance of bands of lower molecular weight indicate hydrolysis of casein proteins to different extents which were also supported by the values observed for degree of hydrolysis.

\subsection{Antioxidant activity of camel milk casein hydrolysates}

Antioxidant activities of camel milk casein hydrolysates were determined using ABTS, DPPH and FRAP assays. The results of these parameters were critically analysed and presented in Figs. 4, 5 and 6 in relation to the hydrolysis time and degree of hydrolysis.

\subsubsection{ABTS radical-scavenging activity}

The ABTS radical-scavenging activity increased significantly $(P<0.05)$ with the advancement hydrolysis time up to $6 \mathrm{~h}$ for alcalase- and papain-treated caseins whereas, for $\alpha$-chymotrypsin-treated casein, it increased significantly $(P<0.05)$ up to $4 \mathrm{~h}$; thereafter, a non-significant increase was observed. As compared to the other two enzymes, hydrolysates produced by $\alpha$-chymotrypsin had significantly $(P<0.05)$ higher antioxidant activity. However, among the two enzymes, i.e. alcalase and papain, hydrolysates produced by alcalase showed significantly $(P<0.05)$ higher ABTS activity.

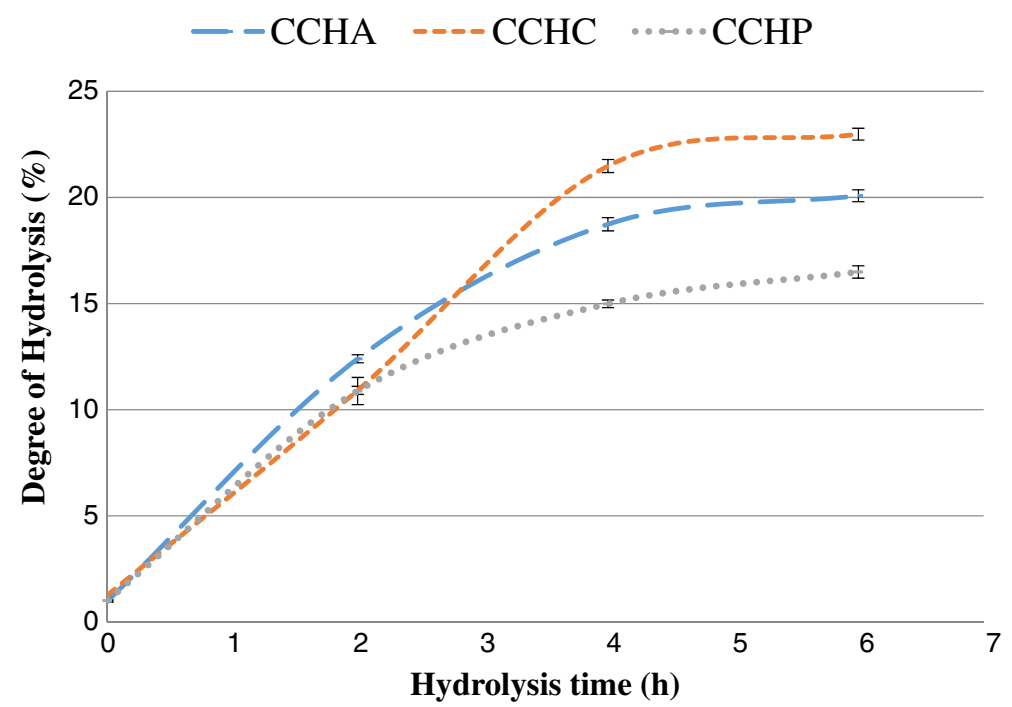

Fig. 2 Degree of hydrolysis (mean \pm SE) of camel milk casein with different enzymes (CCHA camel casein hydrolysate with alcalase, $C C H C$ camel casein hydrolysate with chymotrypsin, $C C H P$ camel casein hydrolysate with papain) $(n=9)$ 


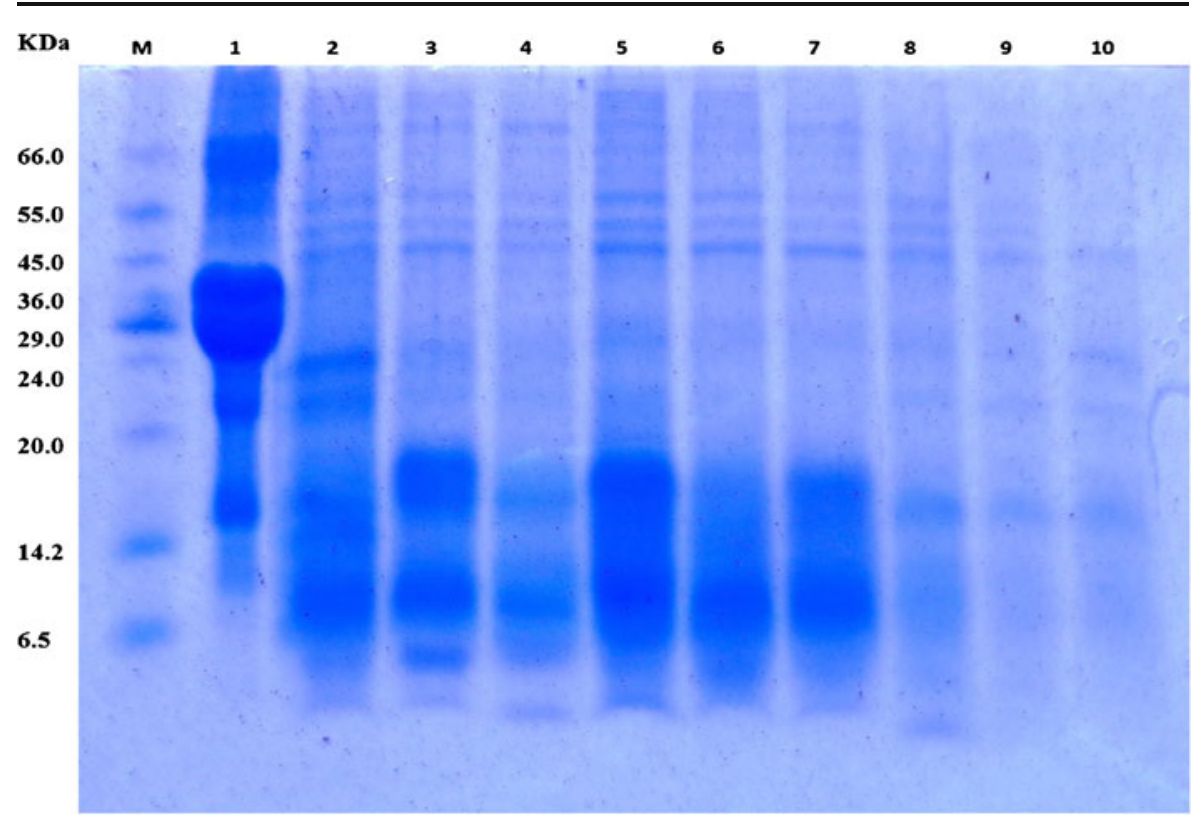

Fig. 3 SDS-PAGE of camel milk casein and its hydrolysates at different hydrolysis time. ( $M$ molecular weight marker; 1 whole casein; 2-4 alcalase-treated casein at 2nd, 4th and 6th hour; 5-7 $\alpha$-chymotrypsintreated casein at the $2 \mathrm{nd}, 4$ th and 6 th hour; $8-10$ papain-treated casein at the $2 \mathrm{nd}$, 4 th and 6 th hour)

\subsubsection{DPPH activity}

The DPPH activity of camel milk casein hydrolysates increased significantly $(P<0.05)$ with the progress in hydrolysis time, and a positive relationship between hydrolysis time and DPPH activity could be established; however, the higher DPPH-scavenging activity was not exhibited after $6 \mathrm{~h}$ of hydrolysis (data not shown). Hydrolysates produced by all

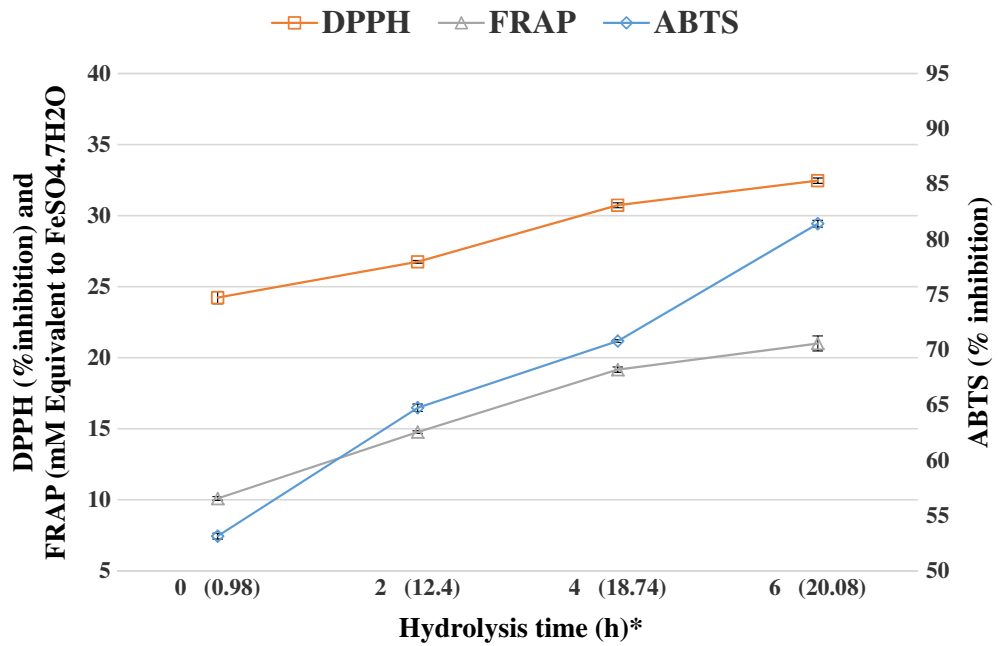

Fig. 4 Antioxidant activities of camel milk casein hydrolysates with alcalase (CCHA) (mean \pm SE) $(*$ the value in parentheses indicates degree of hydrolysis at that time) $(n=9)$ 


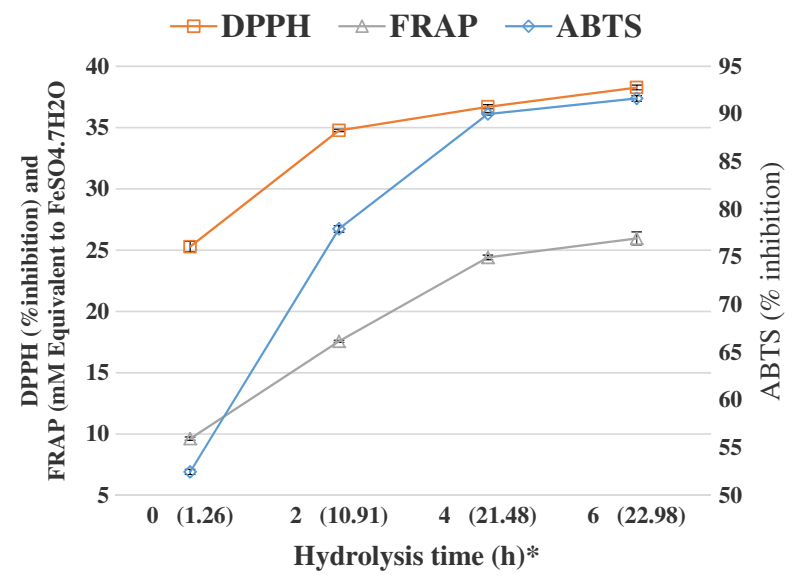

Fig. 5 Antioxidant activities of camel milk casein hydrolysates with $\alpha$-chymotrypsin (CCHC) (mean $\pm \mathrm{SE}$ ) $(*$ the value in parentheses indicates degree of hydrolysis at that time) $(n=9)$

the three enzymes had significantly $(P<0.05)$ increasing DPPH-scavenging activity up to $6 \mathrm{~h}$ of hydrolysis time. As compared to the other two enzymes, the $\alpha$-chymotrypsin produced hydrolysates which had significantly $(P<0.05)$ higher antioxidant activity at $2 \mathrm{~h}$ of hydrolysis and it remained significantly higher up to the 6th hour of hydrolysis. However, after $2 \mathrm{~h}$, the hydrolysates produced by alcalase also showed significantly $(P<0.05)$ higher DPPH-scavenging activity than hydrolysates produced by papain. From the observed pattern of DPPH-scavenging activity, it could be hypothesized that both hydrolyzed and non-hydrolyzed camel milk caseins contain some substances acting as electron donors that could react with free radicals, converting them into more stable molecules and terminating the radical chain reaction.

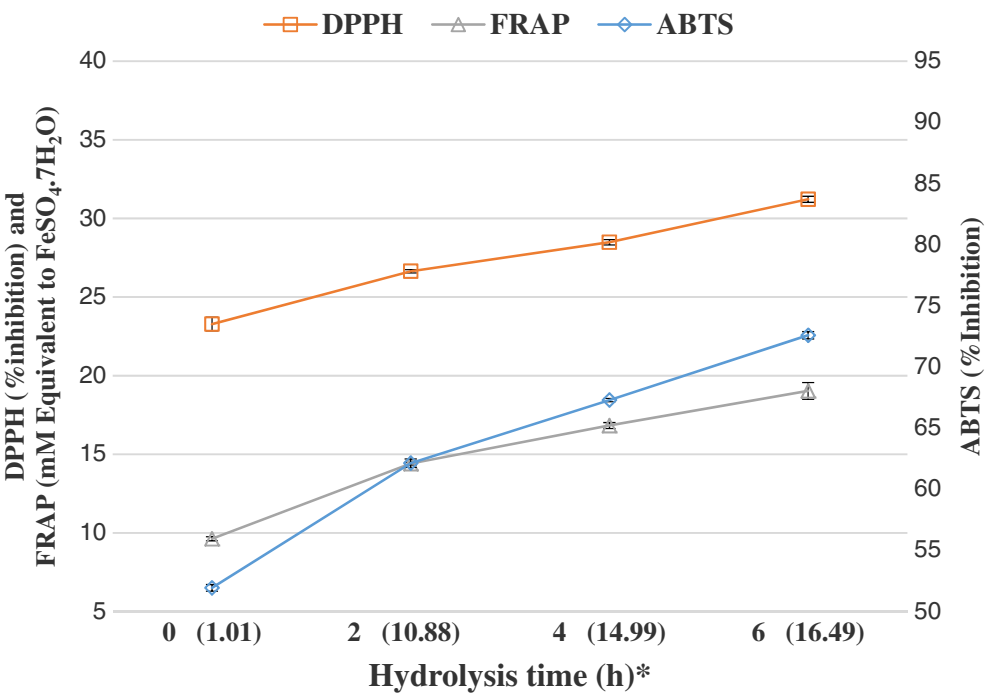

Fig. 6 Antioxidant activities of camel milk casein hydrolysates with papain (CCHP) (mean \pm SE) (*the value in parentheses indicates degree of hydrolysis at that time) $(n=9)$ 


\subsubsection{Ferric reducing antioxidant power}

The results of this experiment showed a positive relationship between hydrolysis time and FRAP value as these values increased significantly $(P<0.05)$ with increase in hydrolysis time. However, among all enzymes, a significantly $(P<0.05)$ higher activity was observed for hydrolysates with $\alpha$-chymotrypsin. The hydrolysates produced by alcalase exhibited higher FRAP values as compared to hydrolysates produced by papain.

\section{Discussion}

\subsection{Change in $\mathrm{pH}$ during hydrolysis}

Enzymatic hydrolysis of proteins is affected by several factors including the structure of the protein, temperature, enzyme/protein ratio, enzyme concentration and $\mathrm{pH}$. Heat denaturation and $\mathrm{pH}$ adjustments are two common ways of making bonds more susceptible to enzymatic action. Change in $\mathrm{pH}$ during hydrolysis may not only affect the enzyme structure, but also changes in structure or properties of the substrate take place which in turn affects the enzyme-substrate binding and thereby hydrolysis. In the current study, phosphate buffers of specific $\mathrm{pH}$ for each enzyme were used to get optimum hydrolysis, but a linear drop in $\mathrm{pH}$ was observed during the hydrolysis process. A similar decrease in $\mathrm{pH}$ of ovine casein hydrolysates with the progress in hydrolysis time was also reported by Daroit et al. (2012). The release of protons $\left(\mathrm{H}^{+}\right.$ion) and/or production of acidic amino acids into the surrounding medium results in reduction in the $\mathrm{pH}$ of the reaction mixture. The number of peptide bonds hydrolysed was estimated from the amount of base required to maintain a constant $\mathrm{pH}$ during the reaction (Adler-Nissen 1986).

\subsection{Degree of hydrolysis}

The reduction of hydrolysis rate in latter hours might also be due to the decrease in $\mathrm{pH}$ of the medium, which might cause denaturation of the protein structure of the enzyme or the disturbances of the ionic character of the substrate, and would in turn affect enzyme-substrate binding. The changes in $\mathrm{pH}$ affect both the substrate and the enzyme by changing the charge distribution and conformation of the molecule, consequently, decrease in rate of hydrolysis. Adler-Nissen (1986) attributed the reduction in hydrolysis rate due to the competition between unhydrolysed protein and the peptides being constantly formed during hydrolysis. The highest levels of $\mathrm{DH}$ obtained with $\alpha$ chymotrypsin suggested that this enzyme has more affinity for the substrate and thus more efficient than alcalase and papain for the production of protein hydrolysates of camel milk casein. Similar results were also reported by Graszkiewicz et al. (2010) in egg-white protein precipitate hydrolysis in which chymotrypsin caused a higher DH in 1-h hydrolysates than trypsin and elastase. Lira et al. (2010) also reported $28.17 \% \mathrm{DH}$ of goat milk casein obtained with the use of papain. In the current study, the DH after $6 \mathrm{~h}$ of hydrolysis had not increased significantly (data not shown). This might be due to enzyme specificity which could not further hydrolyse the remaining bonds within the generated peptides. Carreira et al. (2003) also recommended that the length of the hydrolytic reaction should not be more than $5 \mathrm{~h}$, because beyond this time, it can favour 
the microbial contamination of the protein preparations. Another important reason for keeping shorter hydrolysis time is that longer hydrolysis time often releases bittertasting mixture of peptide and amino acids, which may contribute bitter flavour to the hydrolysates, which ultimately limits their application in food products (Belitz and Grosch 1999). According to Tsou et al. (2010), a limited hydrolysis was required to maintain the structure or sequence of active peptides and to ensure functionality. Furthermore, during hydrolysate production, the cost-benefit relationship should also be taken into account for applying at industrial scale.

\subsection{SDS-polyacrylamide gel electrophoresis}

The principle of separation of proteins and peptides in SDS-PAGE is based on its molecular weight. The intact camel milk casein appeared as major protein as distinct band but in case of hydrolysates, the peptides of lower molecular weight appeared in the bottom of the gel with less resolution which indicates the hydrolysis of proteins. Similar findings were also reported by Saliha et al. (2013) in camel milk proteins following enzymatic digestion with various proteases.

\subsection{Antioxidant activity of camel milk casein hydrolysates}

\subsubsection{ABTS radical-scavenging activity}

The ABTS radical-scavenging activity increased significantly $(P<0.05)$ with the increase in DH over time, and as compared to the other two enzyme-treated samples, hydrolysates produced by $\alpha$-chymotrypsin exhibited significantly $(P<0.05)$ higher antioxidant activity. These findings were in accordance with the findings of Jrad et al. (2014) and Salami et al. (2011) who also reported higher antioxidant activity of camel milk casein hydrolysates upon digestion with gastrointestinal enzymes. Salami et al. (2011) further reported that $\alpha$-chymotrypsin could produce hydrolysates with higher antioxidant activity than trypsin and pepsin. Gomez-Ruiz et al. (2008) also reported higher ABTS activity of ovine casein hydrolysates than intact casein, as observed in the present investigation.

\subsubsection{DPPH activity}

As compared to native casein, the DPPH activity of hydrolysates produced by different enzymes increased significantly. Mao et al. (2011) also reported increase in DPPHscavenging activity of yak milk protein hydrolysates obtained with Alcalase with the progression of hydrolysis process for up to $7 \mathrm{~h}$. The increase in DPPH radicalscavenging activity of camel milk casein hydrolysates was also in agreement with Thiansilakul et al. (2007) and Khantaphanta et al. (2011) who reported the increases in DPPH radical-scavenging activity upon increase in $\mathrm{DH}$ of the hydrolysate from round scad muscle protein prepared using Flavourzyme and alcalase, and brown stripe red snapper muscle prepared using alcalase, respectively. However, some contrast results have also been reported; specifically, bovine casein hydrolysates obtained with diverse proteolytic enzymes were shown to possess lower DPPH activity than the whole protein (Rival et al. 2001). 


\subsubsection{Ferric reducing antioxidant power}

The FRAP method is based on the reduction of complexes of 2, 4, 6-tripyridyl-s-triazine (TPTZ) with ferric chloride hexahydrate $\left(\mathrm{FeCl}_{3} \cdot 6 \mathrm{H}_{2} \mathrm{O}\right)$, which are almost colourless, and eventually slightly brownish. This chemical forms blue ferrous complexes after its reduction. The results of this experiment showed a positive relationship between hydrolysis time. Previous works also suggested that smaller size peptides released by proteolytic enzymes exhibited better reducing power than high molecular weight fractions (Bougatef et al. 2009; Ajibola et al. 2011). Khantaphanta et al. (2011) also reported the increases in FRAP activity of brown stripe red snapper muscle hydrolysate prepared using various proteases.

A positive correlation was also observed in degree of hydrolysis and antioxidant activity for all the enzymes. The increased antioxidant activity through hydrolysis suggested that this process contributed to antioxidant activity by releasing previously inactive peptides encrypted in the sequence of native casein. Khantaphanta et al. (2011) also reported a positive relation between DH and antioxidant activity (DPPH, ABTS and FRAP assay) of the hydrolysate from brown stripe red snapper muscle prepared using various proteases.

\section{Conclusions}

From this study, it can be concluded that camel milk casein could be hydrolysed with proteases such as alcalase, $\alpha$-chymotrypsin and papain to increase its biological activity. The duration of hydrolysis varied with enzyme, and 6-h hydrolysis time was found optimum for alcalase and papain whereas $4 \mathrm{~h}$ for $\alpha$-chymotrypsin to achieve optimum DH as well as antioxidant activities (ABTS, DPPH and FRAP assay). Among different enzymes, $\alpha$-chymotrypsin produced hydrolysates with significantly higher $\mathrm{DH}$ and antioxidant activities. Results suggested that camel milk casein could be used as a natural source of protein to produce hydrolysates with antioxidant activities. It also encourages the use of camel milk caseins and its hydrolysates as antioxidant agents for human consumption and as an ingredient in nutraceutical and pharmaceuticals as well as in different health-oriented food products to enhance its functionalities and shelf life.

Acknowledgment The authors sincerely acknowledge Dr. N. V. Patil, Director, National Research Centre on Camel, Bikaner, Rajasthan, India, for providing facilities for camel milk collection and sample (freeze-dried casein powder) preparation for this research work.

\section{Compliance with ethical standards}

Conflict of interest The authors declare that they have no competing interests.

\section{References}

Adler-Nissen J (1986) Enzymic hydrolysis of food proteins. Elsevier Applied Science Publishers, New York Agrawal RP, Swami SC, Beniwal R, Kochar DK, Sahani MS, Tuteja FC, Ghouri SK (2003) Effect of camel milk on glycemic control, risk factors and diabetes quality of life in type-1 diabetes: a randomised prospective controlled study. J Camel Pract and Res 10:45-50 
Aimutis WR (2004) Bioactive properties of milk proteins with particular focus on anticariogenesis. J Nutr 134: S989-S995

Ajibola CF, Fashakin JB, Fagbemi TN, Aluko RE (2011) Effect of peptide size on antioxidant properties of African Yam Bean Seed (Sphenostylis stenocarpa) protein hydrolysate fractions. Int J of Mol Sci 12: 6685-6702

Beg OU, Bahr-Lindstrom HV, Zaidi ZH, Jornvall H (1985) The primary structure of $\alpha$-lactalbumin from camel milk. European J Biochem 147:233-239

Belitz HD, Grosch W (1999) Food chemistry (2 $2^{\text {nd }}$ ed.). New York, Springer

Benzie IFF, Strain JJ (1999) Ferric reducing/antioxidant power assay: direct measure of total antioxidant activity of biological fluids and modified version for simultaneous measurement of total antioxidant power and ascorbic acid concentration. Method Enzymol 299:15-27

Bougatef A, Hajji M, Balti R, Lassoued I, Triki-Ellouz Y, Nasri M (2009) Antioxidant and free radicalscavenging activities of smooth hound (Mustelus mustelus) muscle protein hydrolysates obtained by gastrointestinal proteases. Food Chem 114:1198-1205

Brand-Williams W, Cuvelier ME, Berset C (1995) Use of a free radical method to evaluate antioxidant activity. LWT Food Sci Technol 28:25-30

Carreira RL, Ornellas CBD, Morais HA, Da-Motta S, Silvestre MPC (2003) Effect of precipitation by trichloroacetic acid (TCA) and ultrafiltration profile on the peptide hydrolysates of casein. Ciencia Agrotecnol 27:414-421

Centenaro GS, Salas-Mellado MM, Pires C, Batista I, Nunes ML, Prentice C (2014) Fractionation of protein hydrolysates of fish and chicken using membrane ultrafiltration: Investigation of antioxidant activity. App Biochem and Biotechnol 172:2877-2893

Chen HM, Muramoto K, Yamauchi F (1995) Structural analysis of antioxidant peptides from soybean $\beta$ conglycinin. J Agri Food Chem 43:574-578

Chen HM, Muramoto K, Yamauchi F, Fujimoto K, Nokihara K (1998) Antioxidative properties of histidinecontaining peptides designed from peptide fragments found in the digests of a soybean protein. J Agri Food Chem 46:49-53

Clare DA, Swaisgood HE (2000) Bioactive milk peptides: a prospectus. J Dairy Sci 83:1187-1195

Daroit DJ, Correa APF, Canales MM, Coelho JG, Hidalgo ME, Tichota DM, Risso PH, Brandelli A (2012) Physico-chemical properties and biological activities of ovine caseinate hydrolysates. Dairy Sci Technol 92:335-351

El-Agamy EI, Nawar M, Shamsia SM, Awad S, Haenlein GFW (2009) Are camel milk proteins convenient to the nutrition of cow milk allergic children. Small Rumin Res 82:1-6

Farah Z (1996) Camel milk properties and products. SKAT, Swiss Centre for Developments Cooperation in Technology and Management, St. Gallen, Switzerland

Gomez-Ruiz JA, Lopez-Exposito I, Pihlanto A, Ramos M, Recio I (2008) Antioxidant activity of ovine casein hydrolysates: identification of active peptides by HPLC-MS/MS. Eur Food Res Technol 227:1061-1067

Graszkiewicz A, Zelazko M, Trziszka T (2010) Application of pancreatic enzymes in hydrolysis of egg-white proteins. Pol J Food Nutr Sci 60(1):57-61

Hartree EF (1972) Determination of protein: a modification of the Lowry method that gives a linear photometric response. Annal Biochem 48:422-427

Hoyle NT, Merritt JH (1994) Quality of fish protein hydrolysates from herring (Clupea harengus). J Food Sci 59:76-79

Jrad Z, El-Hatmi H, Adt I, Girardet JM, Cakir-Kiefer C, Jardin J, Degraeve P, Khorchani T, Oulahal N (2014) Effect of digestive enzymes on antimicrobial, radical scavenging and angiotensin I-converting enzyme inhibitory activities of camel colostrum and milk proteins. Dairy Sci Technol 94:205-224

Kappeler SR, Farah Z, Puhan Z (2003) 5'-Flanking regions of camel milk genes are highly similar to homologue regions of other species and can be divided into two distinct groups. J Dairy Sci 86:498-508

Khantaphanta S, Benjakula S, Kishimurab H (2011) Antioxidative and ACE inhibitory activities of protein hydrolysates from the muscle of brownstripe red snapper prepared using pyloric caeca and commercial proteases. Process Biochem 46:318-327

Li XX, Han LJ, Chen LJ (2008) In-vitro antioxidant activity of protein hydrolysates prepared from corn gluten meal. JSci Food Agri 88:1660-1666

Lira BF, Sobral VB, Silva FO, Dias GMP, Filho JLL, Port TS, Port ALF (2010) Evaluation of variables influencing the enzymatic hydrolysis of casein from goat milk Moxotó. Braz Agri Res 45: doi:10.1590/ S0100-204X2010000900014

Lowry OH, Rosenbrough NJ, Fair AL, Randall RJ (1951) Protein measurement with the Folin-phenol reagents. J Bio Chem 193:265-275

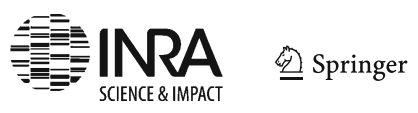


Magjeed NA (2005) Corrective effect of camel milk on some cancer biomarkers in blood of rats intoxicated with aflatoxin $B_{1}$. J Saudi Chem Soc 9:253-263

Mao XY, Cheng X, Wang X, Wu SJ (2011) Free-radical-scavenging and anti-inflammatory effect of yak milk casein before and after enzymatic hydrolysis. Food Chem 126:484-490

Meisel H (2005) Biochemical properties of peptides encrypted in bovine milk proteins. Curr Med Chem 12: 1905-1919

Mohamed A (1993) Characterization of camel milk $\beta$-casein. Ph.D. Thesis, University of Karachi, Pakistan

Rival SG, Boeriu CG, Wicher HJ (2001) Casein and casein hydrolysates. II. antioxidative properties and relevance to lipoxygenase inhibition. J Agri Food Chem 49:295-302

Rossini K, Norena CPZ, Cladera-Olivera F, Brandelli A (2009) Casein peptides with inhibitory activity on lipid oxidation in beef homogenates and mechanically deboned poultry meat. LWT - Food Sci Technol 42:862-867

Salami M, Yousefi R, Ehsani MR, Dalgalarrondo M, Chobert JM, Haertle T, Razavi SH, SabouryAA N-NA, Moosavi-Movahedi AA (2008) Kinetic characterization of hydrolysis of camel and bovine milk proteins by pancreatic enzymes. Int Dairy J 18:1097-1102

Salami M, Yousefi R, Ehsani MR, Razavi SH, ChobertJM HT (2009) Enzymatic digestion and antioxidant activity of the native and molten globule states of camel $\alpha$-lactalbumin: possible significance for use in infant formula. Int Dairy J 19:518-523

Salami M, Moosavi-Movahedi AA, Moosavi-Movahedi F, Ehsani MR, Yousefi R, Farhadi M, Niasari-Naslaji A, Saboury AA, Chobert JM, Haertle T (2011) Biological activity of camel milk casein following enzymatic digestion. J Dairy Res 78:471-478

Saliha SAZ, Dalila A, Chahra S, Saliha BH, Abderrahmane M (2013) Separation and characterization of major milk proteins from Algerian Dromedary (Camelus dromedarius). Emir J Food Agri 25:283-290

Thiansilakul Y, Benjakul S, Shahidi F (2007) Antioxidative activity of protein hydrolysate from round scad muscle using Alcalase and Flavourzyme. J Food Biochem 31:266-287

Tsou MJ, Kao FJ, Tseng CK, Chiang WD (2010) Enhancing the anti-adipogenic activity of soy protein by limited hydrolysis with flavourzyme and ultrafiltration. Food Chem 122:243-248 